\title{
Maximus Confessor's Interpretation of Abraham's Hospitality in Genesis 18 and the Preceding Orthodox Tradition
}

\author{
Grigory Benevich \\ Russian Christian Academy for the Humanities, St. Petersburg, Russia \\ grbenevitch@gmail.com
}

\begin{abstract}
In Orthodox exegesis, there are two main interpretations of God's theophany to Abraham in Gen 18: the three 'men' were either the pre-incarnate Christ and two angels, or, later, they were a type of the Trinity. This article deals with Maximus the Confessor's exegesis of this passage. His interpretations are treated in the context of his teaching on love, his philosophical ideas and his mystical teaching. It shows that Maximus' exegesis can be understood as a creative synthesis of the preceding Orthodox tradition's two interpretations.
\end{abstract}

\section{Keywords}

Orthodox exegesis - Maximus the Confessor - theophany - Old Testament

After Pascal, (who confronted Abraham's God with the god of the philosophers and scholars), it would be appropriate to ask who was Abraham's God from the point of view of Maximus the Confessor, rightly called one of the greatest philosophical minds among the Greek Fathers.

* This article uses the materials of the research project, supported by the Russian Humanitarian Foundation (Project 14-63-01003). I express my gratitude for the discussion of this paper's main ideas with Arkadi Choufrine. I am also grateful to ESally Vickery and Jeremy Wallace who assisted me with the English expression. 
Maximus' interpretation of Abraham's hospitality (Gen 18) in the context of the preceding Christian tradition has been briefly discussed already in the wellknown article by Lars Thunberg. ${ }^{1}$ As for the interpretation of Gen 18 in Christian patristic and Jewish literature, this has been the subject of many studies. Among others, one can mention the chapter "Abraham's Angels: Jewish and Christian Exegesis of Genesis 18-19" in the book by Emmanouela Grypeou and Helen Spurling ${ }^{2}$ and the recent article by Bogdan G. Bucur. ${ }^{3}$

Maximus Confessor's interpretation of Abraham's hospitality is mentioned in all these studies. Besides these, a description and analysis of his interpretations can be found also in some works by modern Maximus scholars, particularly in Melchisedec Törönen's well known study. ${ }^{4}$ Although I will partly use these works, I will not repeat their details. Instead, I will pay attention to those aspects of Maximus' interpretation that have not come under close study. The main stress will be placed on the connection between Maximus' teaching on love and his interpretation of Abraham's hospitality. I will also touch upon Maximus' teaching on his most mysterious notion - rvw $\mu \eta$.

Before analysing Maximus' understanding of Abraham's hospitality, let me summarize the interpretations of Gen. 18 in the Orthodox theological tradition. I will speak mostly about the Greek patristic tradition that was relevant for Maximus. In the 6th century, Procopius of Gaza had already summarized the exegetical traditions of interpretations of this passage from the perspective of the theological problems of his time: "Some consider the three men to be three angels, the 'Judaisers' allege that one of them is God and the other two are angels; and there are also those, who suggest that they (the men), who are addressed as 'Lord' in the singular, are a type for the Holy and Consubstantial Trinity". 5

The Jewish, rabbinical interpretation stated that the three angels were Michael, Gabriel and Raphael. This exegesis separated Gen 18:1 as God's epiphany from Gen. 18: 2-3, understood as the three angels' visit. As Grypeou and Spurling pointed out: "it is clear from all the rabbinic sources ... that the Rabbis

1 L. Thunberg, "Early Christian Interpretation of the Three Angels in Gen. 18," SP 7/TU 92 (1966), pp. $560-570$.

2 E. Grypeou, H. Spurling, The Exegetical Encounter between Jews and Christians in Late Antiquity (Jewish and Christian Perspectives 18), Leiden-Boston, 2009, pp. 181-204.

3 B. Bucur, "The Early Christian Reception of Genesis 18: From Theophany to Trinitarian Symbolism," JECS 23:2 (2015), pp. 245-272.

4 M. Törönen. Union and Distinction in the Thought of St Maximus the Confessor (Oxford Early Christian Studies), Oxford, 2007, pp. 72-76.

5 Procopius of Gaza. Commentary on Genesis XVIII in PG 87, col. 364a-b, cited from: Grypeou, Spurling, The Exegetical Encounter between Jews and Christians in Late Antiquity, p. 190. 
emphasize that God, followed by three angels, visited Abraham, with God appearing to Abraham in Gen 18:1 followed by the visit of the three angels in Gen 18:2".6

Beginning from the second, or even the first century, Christian authors thought that it was God's Logos who Himself together with two Angels, visited Abraham. ${ }^{7}$ Thus, D. Hannah suggests that in general the patristic exegetical tradition on the interpretation of Abraham's visitors as the Lord and the angels "may have begun in the first century for the Fourth Gospel records Jesus' claim that he had previously revealed himself to Abraham (John 8:56)...8 In any case, many such fathers and teachers of the Church as Justin the Martyr, Irenaeus of Lyon, Origen, Eusebius of Caesaria and John Chrysostomus ${ }^{9}$ held this very interpretation. It was elaborated apologetically with the aim of proving the preeternal existence of the Logos. Unlike God the Father, who is absolutely transcendent, the Logos, according to this exegesis, appeared to the righteous of the Old Testament. In these early interpretations, the reality of the Logos' epiphany was stressed. It was not an image of the Logos, but He himself that appeared to the righteous.

The interpretation of Gen 18:1-3 as an epiphany of the Logos accompanied by two angels was based on the understanding of the Logos as a mediator between the Father, who is transcendent and concealed, and the world. Such a relatively lower place for the Logos in comparison with the Father was rejected in the period of the Trinitarian controversy of the 4th century. Little by little, the new one substituted the previous exegesis of Gen 18. As we learn from Procopius of Gaza, (cited above), in the 6th century, the authors of the previous interpretation were called the "Judaisers", even though, as we could see, there were a lot of the Church Fathers among them. ${ }^{10}$ In the West in the 4 th century, both Christological and Trinitarian interpretations are already found ${ }^{11}$ in Ambrosius of Milan and in Prudentius. However, it seems that for the Greek Fathers such a combination was not typical and we find the substitution of the one interpretation for the other in their writings, as is clearly seen from Procopius of Gaza.

6 Grypeou, Spurling, The Exegetical Encounter between Jews and Christians in Late Antiquity, p. 189 .

7 Ibid., p. 190-191.

8 D.D. Hannah, Michael and Christ: Michael traditions and angel Christology in early Christianity, Tübingen, 1999, p. 112.

9 Grypeou, Spurling, The Exegetical Encounter between Jews and Christians in Late Antiquity, p. 195 .

$10 \quad$ Ibid., p. 196-197.

11 Bucur, "The Early Christian Reception of Genesis 18," p. 256. 
Thus already Cyril of Alexandria in Contra Julianum I "established that the episode at Mamre was a revelation of the Holy Trinity and accordingly Abraham, although he saw three persons, addressed them as if they were one. The three men also talked as one person. Abraham was therefore aware of the mysteries of the Trinitarian nature of God".12 As Grypeou and Spurling noted, among the Greek Fathers: "the Trinitarian interpretation of Genesis 18 can be found not earlier than the fifth century". This interpretation, with the specification that three angels or three men who visited Abraham were a type or an image of the Holy Trinity, became classical for the Greek patristic tradition. This very exegesis is reflected in the Eastern Orthodox hymnography, particularly, in the hymns of the Sunday Midnight Office, ${ }^{13}$ and iconography, particularly in the famous icon of the Holy Trinity by Andrey Rublev. ${ }^{14}$ It is not the Trinity as such that is depicted on the icon, since the Trinity cannot be depicted. Rather it is three angels seen as a type of the Trinity. Such is a classical Orthodox interpretation of this icon.

At first glance, a similar interpretation can be found as late as the seventh century in Maximus the Confessor. As Grypeou and Spurling put it: "Maximus notes that Abraham was taught the Trinity in the unity, as God appeared to him as three and conversed to Him as one (Quaestiones ad Thalassium 28)". ${ }^{15}$ However, the situation is more complex, and some of Maximus' interpretations were not strictly Trinitarian as were those of Cyril of Alexandria. Though we cannot find a verbal Christological interpretation of this place in Maximus, I believe, however, that Maximus somehow combined those two Christian traditions of the Gen 18 interpretation in his mystical interpretation of this passage in Letter 2 "On love, to John the Cubicularius". Let us attentively read the relevant passages from that letter.

Maximus dealt with the exegesis of Gen 18 in his Letter 2 On Love, to John the Cubicularius (Ep. 2: PG 91, col. 40oc-d), in Questions and Doubts 39, ed. Declerck

12 Grypeou, Spurling, The Exegetical Encounter between Jews and Christians in Late Antiquity, p. 195

13 Bucur, "The Early Christian Reception of Genesis 18," p. 259. Bucur notes that Romanos the Melodist viewed the Mamre theophany as a christophany, but his sixth-century compositions represented the earlier tradition.

14 G. Bunge, The Rublev Trinity: The Icon of the Trinity by the Monk-Painter Andrei Rublev. Crestwood, NY, 2007; A. Louth, "The Oak of Mamre, the Fathers and St. Andrei Rublev: Patristic Interpretation of the Hospitality of Abraham and Rublev's Icon of the Trinity," in The Trinity-Sergius Lavra in Russian History and Culture, ed. Vladimir Tsurikov, Jordanville, NY, 2005, pp. 90-100.

15 Grypeou, Spurling, The Exegetical Encounter between Jews and Christians in Late Antiquity, p. 195 . 
and in Questions and Answers to Thalassius 28, ed. Laga/ Steel. Until now, more attention was paid to the latter two interpretations in Maximus' scholarship. However, in the context of my paper, to my mind Letter 2 is more interesting, and I will deal mostly with it.

One of the main sources of inspiration for Maximus in the Letter 2 was Apostle Paul, whose teaching on love greatly influenced Maximus' teaching on love, developed in the "Centuries on Love" and in Letter 2. Abraham's ability to see God was understood in Letter 2 with the help of the notion of love to humankind. As Maximus put it: "Great Abraham ... was made worthy to see God as

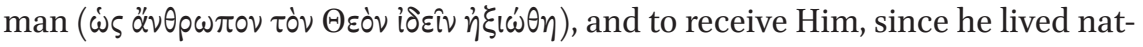
urally in accordance with the perfect natural logos through love for humankind. He was led up to this, having relinquished the individuality of what divides and is divided, no longer leading another human being different from himself, but knowing all as one and one as all".16

Thus, according to Maximus, God's revelation to Abraham through three men was possible because Abraham, through love for humankind ( $\varphi i \lambda \alpha \nu \theta \rho \omega \pi i \alpha)$, acknowledged all men "as one and one as all". What does $\varphi i \lambda \alpha \nu \theta \rho \omega \pi i \alpha$ mean here? I will try to answer this question later. Now, I want to note that this passage from Letter 2 was influenced by the famous passage from the Paul's Epistle to Galatians, where he says that for Christians "There is neither Jew nor Gentile, neither slave nor free, nor is there male and female, for you are all one in Christ Jesus" (Gal 3:28) and from his Epistle to Colossians, where it is said that in Christ "is no Gentile or Jew, circumcised or uncircumcised, barbarian, Scythian, slave or free, but Christ is all, and is in all" ( $\mathrm{Col} 3: 11)$. In the Epistle to Galatians immediately after the above-cited verse, we find another one where Abraham is mentioned: "If you belong to Christ, then you are Abraham's seed, and heirs according to the promise" (Gal 3:29).

As we see from Letter 2, Abraham appears to be a model or an archetype of a person who has overcome all divisions in humanity, and "Abraham's seed" are all those who are similar to him in that respect. Maximus directly addressed the above mentioned verses from Paul's Epistles to the Galatians and Colossians in his "Centuries on Love" (2.30): "He who is perfect in love and has attained the summit of detachment knows no difference between 'mine and thine,' between faithful and unfaithful, between slave and freeman, or indeed between male and female, having risen above the tyranny of the passions and looking on the

16 Maximus Confessor, Ep. 2: PG 91, 40oc, translation by Andrew Louth (A. Louth, Maximus the Confessor (Early Church Fathers), London, 1996, p. 86) with some minor but impor-

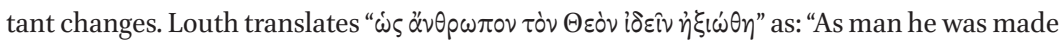
worthy to see God" instead of my translation: "was made worthy to see God as man". 
nature, one in all men, he considers all equally and is disposed equally to all. For in him ${ }^{17}$ there is neither Greek nor Jew, neither male nor female, neither slave

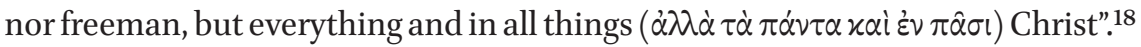

Maximus reinforced and actualized this series of opposites that must be overcome by "he who is perfect in love." He added the opposites "faithful and unfaithful" in place of "circumcised and uncircumcised" to Paul's list. Thus for Maximus, perfect love could not only take place between Christians, the members of Christ's body, but could also characterize the perfection in the love to be found in their relationship with any person. As we see from Abraham's example, such a person "who is perfect in love" could even have lived before the historical Incarnation, anticipating it in the spirit of love.

Comparing the passage from the "Centuries on Love" with the relevant places in Letter 2, one can note that Maximus' saying that Abraham knew "all as one and one as all" said nothing of Christ. However, there is implicit parallel of this place to the places from Paul's Epistles, where it is said: "Christ is all, and is in all” (Col 3:11). Maximus understood Abraham's perfection in love within the same paradigm. We now have to reveal its essence.

However, before doing so, it is necessary to note that Maximus' statement that the one perfect in love equally loves every person, was made in implicit polemics with Evagrius of Pontus, who had written that "it is impossible to love equally all brothers, but it is possible to treat all of them dispassionately without hatred and rancor". ${ }^{19}$ It seems that this phrase was a challenge for Maximus, because it is contradicted by Christ's words from the Sermon on the Mountain which make a call to love everybody, including enemies (see Math 5:44-48). The theme of the equal love for everybody is in the centre of many chapters in Maximus' "Centuries on Love". I have counted five passages beginning with "Blessed is the man who can equally love each person" (1.17), and including passages 1.25; 1.61; 1.71 and 2.10 .

In the context of the interpretation of Abraham's hospitality in Letter 2, one passage from the "Centuries on Love" is of special interest: "Perfect charity does not split up the one nature of men according to their various dispositions ( $\gamma \nu \omega \dot{\mu} \mu \mathrm{s})$; but always looking to that nature, loves all men equally, the zealous as friends, the bad as enemies. It does them good and is patient and puts up with the things they do". ${ }^{20}$

17 Polycarp Sherwood (see the next note) reads "in Him", but to my mind this reading, though possible, is superficial. Saint Maximus the Confessor. The ascetic life: The four centuries on charity (Ancient Christian Writers), trans. by P. Sherwood, Chicago, 1955, p. 138. Maximus Confessor, Char. 1.71, trans. by P. Sherwood, Saint Maximus the Confessor, p. 146. 


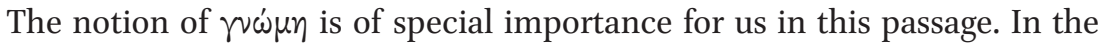
context of Abraham's hospitality in Letter 2 Maximus dealt a lot with this notion, that which can be translated here as disposition or as inclination of the will. As we know, that notion would have a long and complicated history in Maximus' works in the context of polemics with the Monothelites. In those polemics Maximus would reject the gnomic will or " $\gamma v \omega \mu \eta \eta$ " in Christ, and would say that in the saints $\gamma \nu \omega \dot{\mu} \mu \eta$ is totally passive, being delivered to God. ${ }^{21}$ However, in the period before the polemics with the Monothelites, using this term in a

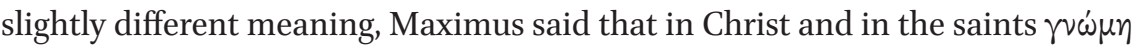
is completely concurrent with the logos of nature, that is God's will concerning human nature. ${ }^{22}$ This oneness with God has its effect on how the saints look at all human beings.

Speaking about Abraham in Letter 2, Maximus said that he knew "all as one and one as all, looking certainly not on the logos of the [gnomic] will ( $\gamma$ wáns) about which there is contention and division, while it remains irreconcilable with nature, but on the logos of nature itself, [the nature,] that remained unchangeable". ${ }^{23}$ This passage is very close to the passage from Char. 1.71 cited above.

However, even more interesting for us is that after saying that Abraham looked on the logos of nature instead of the dividing logos of the [gnomic] will ( $\gamma v \omega \dot{\omega} \mu \eta \varsigma)$, Maximus added something especially important for our theme:

In Opusc. 1, PG 91, 24c Maximus described the state of perfect deification as the state with no gnomic will and deliberate choice; in that state the change from virtue to vice, that is, changeability related to the things in our control (and gnomic will acts exactly on that kind of things) is no longer possible. See on this matter: I.A. McFarland, "Willing Is Not Choosing': Some Anthropological Implications of Dyothelite Christology," International Journal of Systematic Theology, 9.1 (2007), pp. 3-23.

See Maximus Confessor, Ep. 2: PG 91, col. 400a-b. At the time of his polemics with the

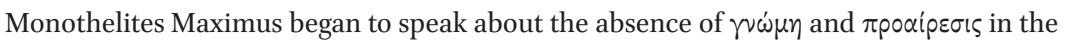
saints in the state of deification, while he described the state of deification somewhat differently prior to the onset of the debate, for example, by saying that the volition of the saints became unalterable because of deification (see Thal. 6.28-38 Laga/Steel). This

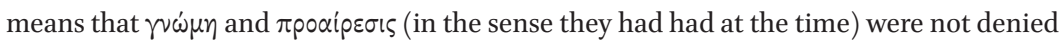
in the earlier period as applied to Christ or to the saints, and Maximus only said that saints became unshakable in Goodness. At the same time, we should not forget that in the early period Maximus professed the doctrine of the "unified energy of God and the saints" (see Amb. 7, PG 91, 1076a-b) in the state of deification, and it is within the context of this doctrine, that is, proceeding from the concept of complete deification of the volitional principle in the saints (when free will was fully given up to the will of God), that Maximus

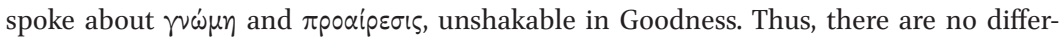
ences in the essence of the doctrine in the early and later works of Maximus. 
"through this [logos of nature], together with it, as we know, God manifests, and through this logos He is set forth as good, making the creatures His own ( $\tau \dot{\alpha}$ ' $\delta$ เ $\alpha$

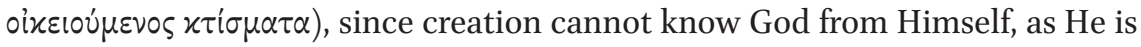
in Himself". ${ }^{24}$ This passage is very interesting and complicated.

To my mind, Maximus said here that God manifests in a specific way through each human being, and saints, such as Abraham can see it. In fact, according to this passage, each human being is God's own, and that is why Abraham saw God in each of the three men. Thus, one God is seen by Abraham as three different persons as one Prototype through three images. (By default that was expressed in Abraham's addressing them as one Lord). Such was Maximus' understanding of the Abraham's hospitality and its relation to the Trinitarian doctrine.

It is important to stress here that, according to Maximus, Abraham had this vision through the logos of human nature. It means that God makes all human nature His own. However, each human being is a member of humanity; thus from this perspective of belonging to humanity, each human being is God's own. At the same time, in what divides us from the human nature, in all our selfishness and self-love, we are not God's own. ${ }^{25}$ However, it is our fault; God makes all human beings His own. Certainly, there is an implicit Christological allusion here. ${ }^{26}$

Thus receiving three men as identical with him in nature, Abraham acknowledged, in them and through them, God as the Good Father and Creator of all human beings. If we now return to Maximus' statement that Abraham knew "all as one and one as all", it does not mean to my mind that all human beings were

24 Ep. 2, PG 91, col. 40od.

25 In Char. 1.25 Maximus said of God, that He loves all men equally, but "the virtuous man $\mathrm{He}$

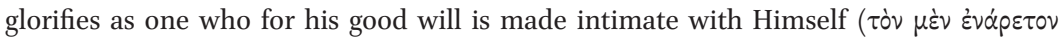

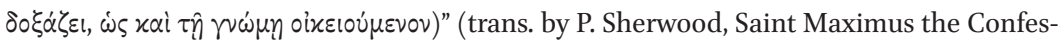

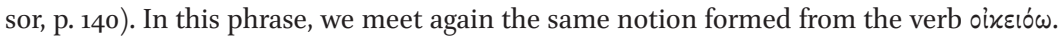
However, Maximus was speaking there not only about oix $\varepsilon^{\prime} \omega \sigma \iota \varsigma$ of nature as in Letter 2,

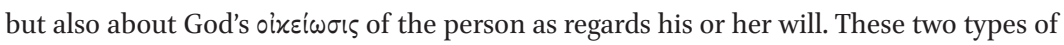

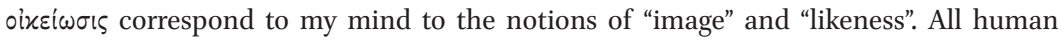
beings as God's image are God's own, and God can be seen in them and through them as their Father and Creator, but only saints are God's own as His image and likeness; not only God can be seen in them, but the saints themselves can be seen in God (in Char. 1.25 Maximus speaks about their glorification). In Letter 2 Maximus did not say that Abraham's guests were virtuous men, it was not important for his argument. God manifested in them and through them for Abraham not because they were virtuous, but because he was!

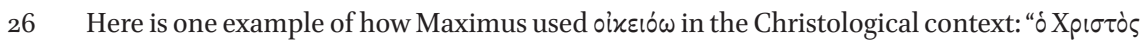

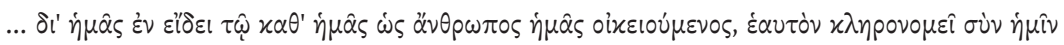

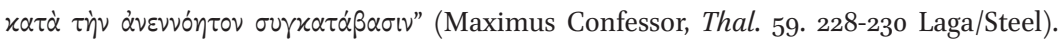
Maximus says here, above all, that Christ as God made us His own in the Incarnation. 
exactly alike for Abraham, that is totally identical. It means, I think, that for Abraham each human being was God's own, and Abraham's love for humankind $(\varphi \imath \lambda \alpha \nu \theta \rho \omega \pi i \alpha)$ in relation to any human being, was God's love for humanity. It is that very God's love for humankind that God perfectly revealed by becoming man in Christ.

If we now compare Maximus' interpretation of Abraham's hospitality in Letter 2 with the interpretation of the Greek Fathers before him, we can see several similarities and differences. Maximus did not say that only one person who visited Abraham was the Logos' theophany, the other two being angels. He did not mark out one person from two others. At the same time as many early teachers and Fathers of the Church, Maximus spoke about the reality of God's manifestation or epiphany to Abraham. Three men who visited him were not just a type of the Trinity (interpretation classical for the Orthodox Church since the 6th century), but God's real epiphany.

In fact, Maximus' interpretation mysteriously combined two previous traditions of Abraham's hospitality interpretation. He did not say that the three Persons of the Trinity were personally present to Abraham in the image of three men. However, he did say about the reality of the theophany: "Great Abraham ... was made worthy to see God as man and to receive Him". ${ }^{27}$ Thus, Abraham knew the One God revealed to him simultaneously in three different men that is in the three persons, equally loved by God and made His own. The Christological dimension, (prophesy about the Incarnation), is mysteriously combined with the Trinitarian dimension. Knowledge of the Trinity became possible through the knowledge of the mystery of the united divine and human natures in Christ.

It is also interesting to note that, strictly speaking, Maximus did not mention anything miraculous in this interpretation. According to Letter 2, Abraham acknowledged God in the three men because he was a deified saint and had such a sublime view of things that he could "see God as man", that is, in man, or through man. However, in two other places where Maximus dealt with Gen 18, especially in Thal. 28, he said that it was God who revealed Himself to Abraham, according to Abraham's ability, because Abraham had already overcome the division of matter and form and knew the principle (logos) of the One. ${ }^{28}$ The three guests spoke to Abraham as one: "When God appeared to Abraham, who was perfect in knowledge and had completely detached his mind from matter and its impressions, God taught him that the immaterial word (logos)

27 Maximus Confessor, Ep. 2: PG 91, col. 400c.

28 See analysis in Törönen, Union and Distinction in the Thought of St Maximus the Confessor, pp. $73-76$. 
concerning the Triad is in the word (logos) concerning the Monad. And it was for this reason that God then appeared as three and conversed as one". ${ }^{29}$ That miraculous detail, which was also mentioned in Cyril of Alexandria, ${ }^{30}$ was not mentioned, however, in Letter 2. It seems that Maximus added this detail because he realized that something was missing in his interpretation from Letter 2, namely God's active role in the revelation of the Trinitarian doctrine to Abraham. Not only has God sent these three mysterious persons to Abraham, but He has also spoken through them as the One, confirming Abraham's own vision that three could be one. Thus, God revealed Himself not only as Good as in Letter 2, but also as Truth, since He confirmed Abraham's personal view. What is objective appeared to be identical with the "subjective".

It is interesting that in Thal. 28 nothing was said about the nature of Abraham's three guests. In Letter 2 they are men; in Question and doubts 39 Maximus agreed that they were angels. ${ }^{31}$ In Thal. 28 their nature was not mentioned. Maximus also did not mention anything about Abraham's love for humankind or angels in Thal. 28. There Maximus' stress was on Abraham's overcoming the matter-form division and on his unity with the One. The Neoplatonic influence is evident. However, being more philosophical in Thal. 28 than in Letter 2 (written earlier), Maximus in Thal. 28 was more religious in a sense. Indeed, he stressed there not only Abraham's virtue of seeing three guests as one, (thanks to his own unity with the One $)^{32}$, but also God's confirmation of Abraham's vision, since God really spoke through them as One.

Returning to Pascal's opposition of Abraham's God to the god of philosophers, one may say that Maximus's God is certainly the god of philosophers, since he was very close to the One and Good of the Neoplatonists. At the same time, He is also the God of Abraham, seen from the Christian perspective. He actively interferes with the human sphere, for example, revealing Himself as it happened with Abraham. This revelation, however, was possible, according to Maximus, thanks to Abraham's philosophical virtues. Such virtues were Abraham's love for humankind and contemplation of the human nature's logos or the overcoming of the matter-form duality and his unity with the One.

\footnotetext{
29 Maximus Confessor, Thal. 28: 10-15 Laga/Steel, trans. by M. Törönen (Törönen, Union and Distinction in the Thought of St Maximus the Confessor, p. 75).

30 Cyril of Alexandria. Contra Iulianum 1.26 (see Grypeou, Spurling, The Exegetical Encounter between Jews and Christians in Late Antiquity, p. 195).

$31 \quad$ See Maximus Confessor, Qu. dub. 39.7 Declerck.

32 See also Maximus Confessor. Ambigua, 10.43, PG 91, col. 1193d.
} 